\title{
The Passion Fruit in Florida ${ }^{1}$
}

\author{
Mark Bailey, Ali Sarkhosh, Amir Rezazadeh, Joshua Anderson, Alan Chambers, and Jonathan \\ Crane $^{2}$
}

Scientific name: Passiflora edulis Sims

Common names: passion fruit (English), parcha and maracuyá (Spanish), maracujá (Portuguese), lilikoi (Hawaiian), buah susu (Malya), linmangkon (Thailand), chum bap (Vietnamese). Figure 1 shows the flower.

Family: Passifloraceae

Distribution: Various species and cultivars of passion fruit are grown throughout tropical and subtropical areas of the world.

Importance: Estimated worldwide annual passion fruit production is about 1.5 million metric tons, with Brazil as the leading passion fruit producer in the world (Altendorf 2018). Other major producers include Colombia, Peru, Ecuador, Australia, New Zealand, Indonesia, and some African countries. In the United States, passion fruit is grown commercially in Florida, Hawaii, Puerto Rico, and California.

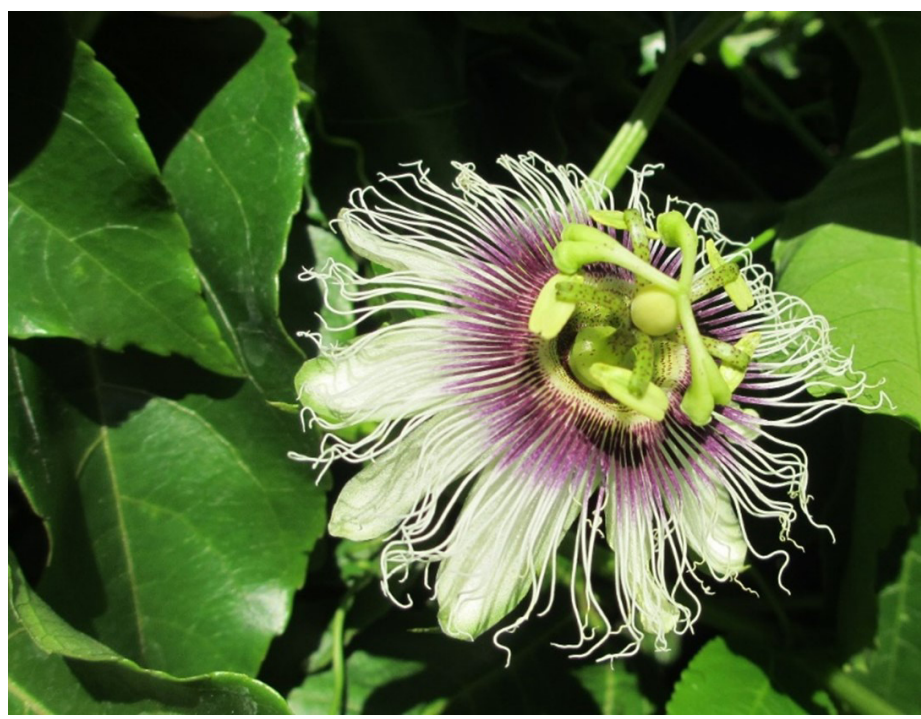

Figure 1. Passion fruit flower. Credits: Mark Bailey, UF/IFAS

\section{History of Passion Fruit}

The first European report of passion fruit was by Cieza de León in 1553 when he was a civil servant in Colombia (Ulmer and MacDougal 2004). He called the fruit "granadilla" (small pomegranates), which was potentially Passiflora ligularis. In 1569, Nicolás Monardes, a physician in Spain, associated the passion flower morphology with the

1. This document is HS1406, one of a series of the Horticultural Sciences Department, UF/IFAS Extension. Original publication date January 2021. Visit the EDIS website at https://edis.ifas.ufl.edu for the currently supported version of this publication.

2. Mark Bailey, sustainable agriculture and food systems Extension agent I, UF/IFAS Extension Marion County; Ali Sarkhosh, assistant professor and Extension specialist, Horticultural Sciences Department; Amir Rezazadeh, multicounty fruit and field crops Extension agent II, UF/IFAS Extension St. Lucie County; Joshua Anderson, graduate student; Alan Chambers. assistant professor; and Jonathan H. Crane, professor and tropical fruit crop specialist, Horticultural Sciences Department, UF/IFAS Tropical Research and Education Center; UF/IFAS Extension, Gainesville, FL 32611.

The use of trade names in this publication is solely for the purpose of providing specific information. UF/IFAS does not guarantee or warranty the products named, and references to them in this publication does not signify our approval to the exclusion of other products of suitable composition.

The Institute of Food and Agricultural Sciences (IFAS) is an Equal Opportunity Institution authorized to provide research, educational information and other services only to individuals and institutions that function with non-discrimination with respect to race, creed, color, religion, age, disability, sex, sexual orientation, marital status, national origin, political opinions or affiliations. For more information on obtaining other UF/IFAS Extension publications, contact your county's UF/IFAS Extension office. U.S. Department of Agriculture, UF/IFAS Extension Service, University of Florida, IFAS, Florida A \& M University Cooperative Extension Program, and Boards of County Commissioners Cooperating. Nick T. Place, dean for UF/IFAS Extension. 
crucifixion of Christ. Subsequently, the passion fruit flower was used by early missionaries in Brazil as an illustrative aid in an effort to convert the indigenous population to Christianity. Specifically, it was referred to as "flower of the five wounds" to represent Christ's crucifixion. The symbolism endured such that Carl Linnaeus established the scientific name of the genus Passiflora (Latin for passion flower) in 1737 (Kugler and King 2004).

\section{Passion Fruit Taxonomy}

Passion fruit is a short-lived evergreen perennial vine that produces an aromatic and tropical-tasting fruit. The most commonly cultivated types in the United States are the purple passion fruit (Passiflora edulis) and, to a lesser extent, the yellow passion fruit (known as $P$. edulis flavicarpa). Currently evidence suggests $P$. edulis and $P$. edulis f. flavicarpa are morphologically and genetically of the same species, and therefore P. edulis is the preferred genus species designation (Bernacci et al. 2008; Silva and Santos 2020). P. edulis is native to the regions of Brazil, Paraguay, and northern Argentina and is grown worldwide in suitable climates (Ulmer and MacDougal 2004). There are more than 500 species within the Passiflora genus, while only a small number produce edible fruit. Most are tendrilbearing vines, and many have ornamental value.

While $P$. edulis is most commonly grown, there are other species within the Passiflora genus that are of agricultural significance: sweet passion fruit (P. alata) has yellow to orange fruit; sweet granadilla ( $P$. ligularis) has an orange shell when ripe; water lemon ( $P$. laurifolia) has yellow or orange fruit and coconut flavor notes; sweet calabash (P. maliformis) has round yellow-brown fruit; and giant granadilla ( $P$. quadrangularis) has greenish-yellow fruit up to 8 inches long. $P$. incarnata, commonly called maypop or "passion flower" (not to be confused with P. edulis), is the most cold-hardy species native to the southern United States, and it has yellow to green fruit that are insipid to slightly sweet.

\section{Adaptation}

Passion fruit are adapted to tropical and semitropical climates, such as Florida. USDA hardiness zones $9 \mathrm{~b}$ and above are suggested for $P$. edulis. Under favorable conditions, new plants grow vigorously and typically begin producing flowers and fruit within a year of planting (Figure 2). The life span of a productive passion fruit vine is typically about three to four years, though they may occasionally live longer. The true purple passion fruit is said to be adapted to high-elevation environments in the tropics. In contrast, yellow types and purple-yellow hybrids are considered better adapted to lower, warmer elevations. Passion fruit prefer well-drained soil and have shallow root systems. As such, the vines have limited drought and flood tolerance (Queensland Department of Agriculture and Fisheries 2016). Mature vines with dense foliage may tolerate temperatures slightly below freezing with some loss of foliage, though exposure to temperatures in the mid-20s (degrees Fahrenheit) may result in entire aboveground vine death that may not resprout from the underground tissue (Campbell et al. 1977).

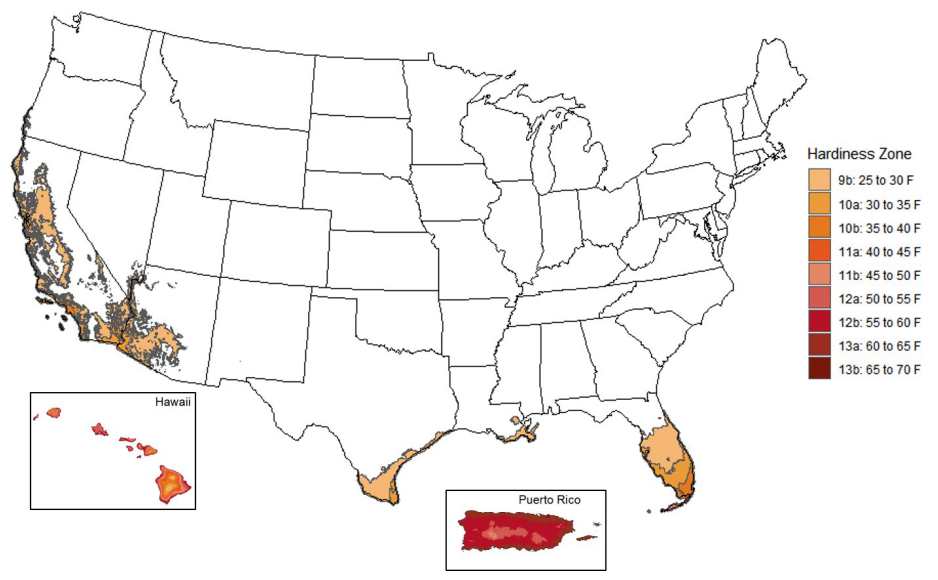

Figure 2. USDA Hardiness zones appropriate for P. edulis cultivation; data from USDA ARS OSU (2012)

Passion fruit is not listed on either the USDA Florida noxious weeds list or the Florida Exotic Pest Plant Council's list of Invasive Plant Species.

\section{Description of Vine}

Growth Habit: Passion fruit grow as perennial lianas or woody vines that grow to great length, often covering the tops of mature trees when growing naturally (Figure 3 ). While mature vines' total length can exceed $100 \mathrm{ft}$, they can also grow more than $35 \mathrm{ft}$ in a single year. As new growth emerges from the tips of vines, flower buds emerge along with young leaves and tendrils. The vine's tendrils help it climb and remain secure as they wrap around objects they come in contact with. Vines that are in shade or partial shade typically drop their leaves.

Leaf Morphology: Passion fruit leaves typically grow up to 8 inches long, and they are green, glossy on top, paler and dull underneath, single, and alternate. Passion fruit exhibit heteroblasty, which means there is a noticeable difference and transition in leaf shape: the leaves of young seedlings are oval-shaped, while adult leaves are deeply lobed with two indentations and finely toothed (Figure 4). Intermediate leaves can have both adult and young traits. At the base of each leaf are extrafloral nectaries (Figure 5), 
which secrete a sugary solution that attracts nectar-seeking insects, such as ants and bees.

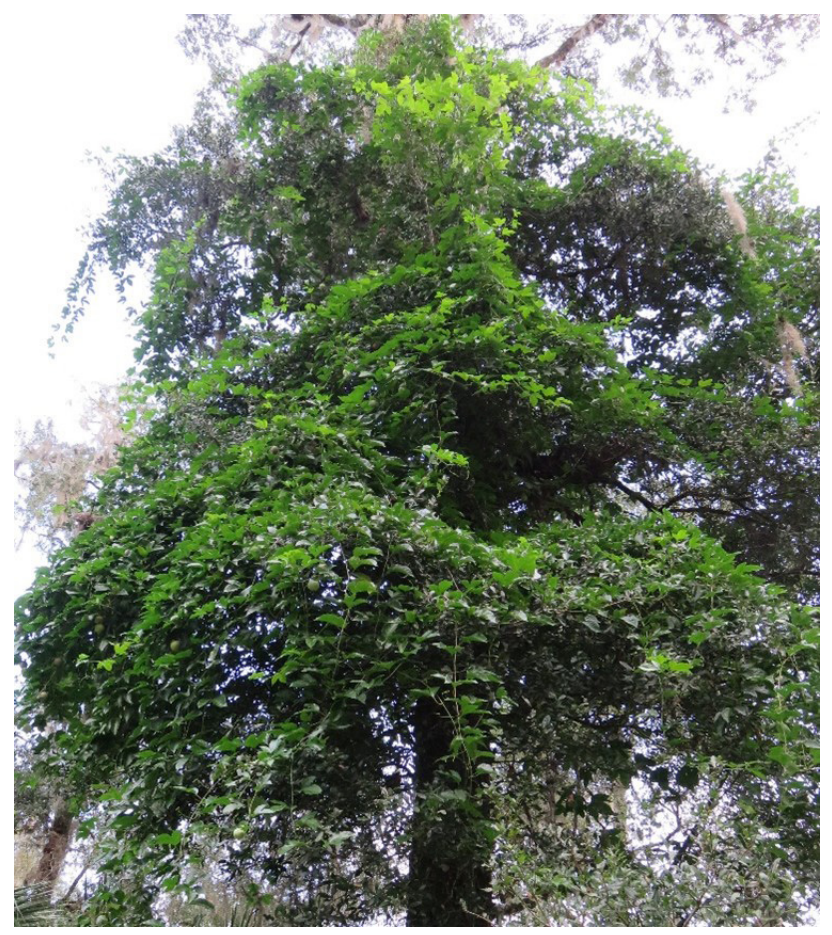

Figure 3. P. edulis 'Possum Purple' climbing a tree.

Credits: Susan Bailey, UF/IFAS

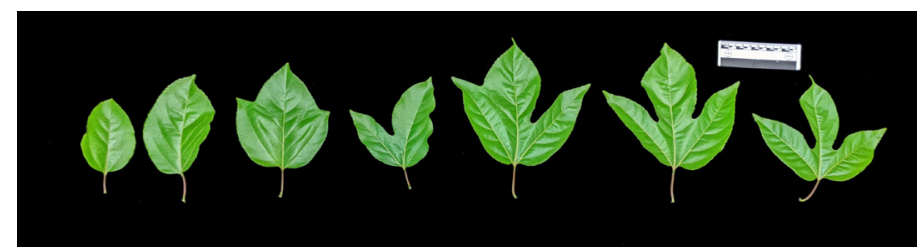

Figure 4. Leaf heteroblasty in P. edulis from juvenile to adult. The transition of young, monolobed leaves on left to adult, trilobed leaves on right.

Credits: Josh Anderson, UF/IFAS

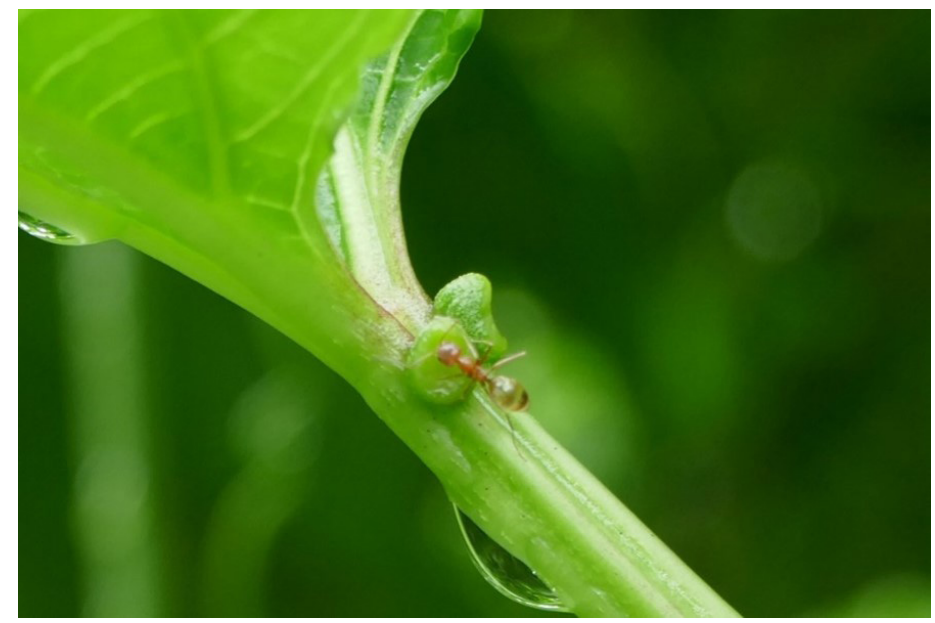

Figure 5. Ant feeding on extrafloral nectary.

Credits: Mark Bailey, UF/IFAS

Flower Characteristics and Morphology: Passion fruit flowers are $2 \frac{1}{2}-3$ inches wide, are slightly fragrant, and face outward, away from the plant (Figure 6 and 7). The flowers are perfect, containing both male and female parts. The flower structure (Figure 8 ) is pentamerous with 5 petals, 5 sepals, and 5 anthers. Below the three-pointed stigma is the ovum, which will grow into the passion fruit if adequately pollinated. Below the anther is the operculum, which contains nectar that attracts nectar-feeding insects. Extending out from the operculum are many coronal filaments, which are dark purple nearest the center and turn white as they extend outward. Underneath the corona filaments are the 5 petals and 5 sepals. The sepals, which are under the petals, can be distinguished from petals by the presence of a green tip. The large carpenter bee (Xylocopa spp.), which has a similar appearance to a bumblebee (Figure 9), is the most effective insect for pollinating passion fruit. Other bees and nectar-feeding insects can also aid in pollen transfer from one flower to another. Some purple varieties can be self-pollinated, while yellow varieties are not considered capable of self-pollinating, and hybrids vary in their self-compatibility.

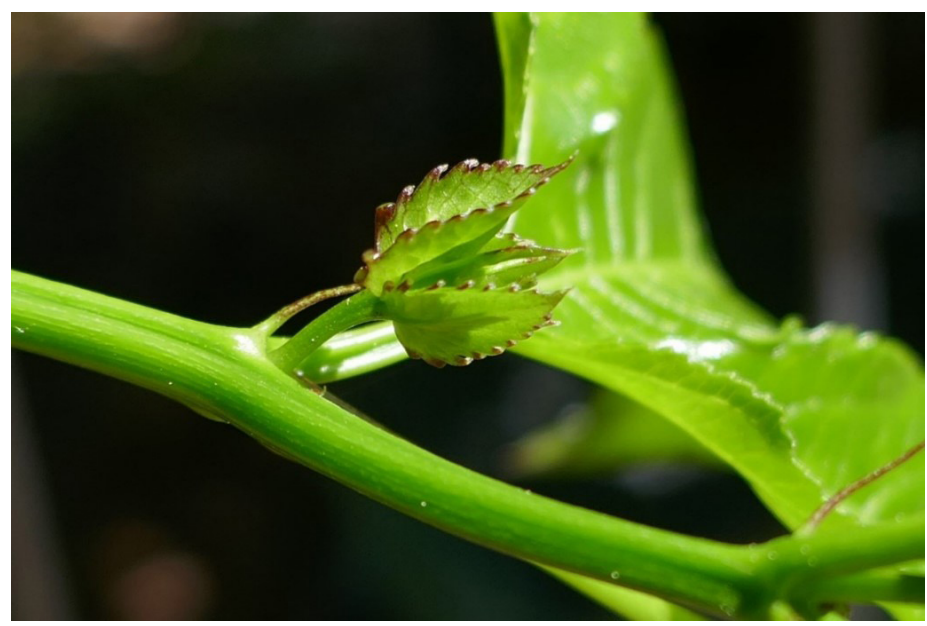

Figure 6. New flower bud emerging on new growth. Credits: Mark Bailey, UF/IFAS

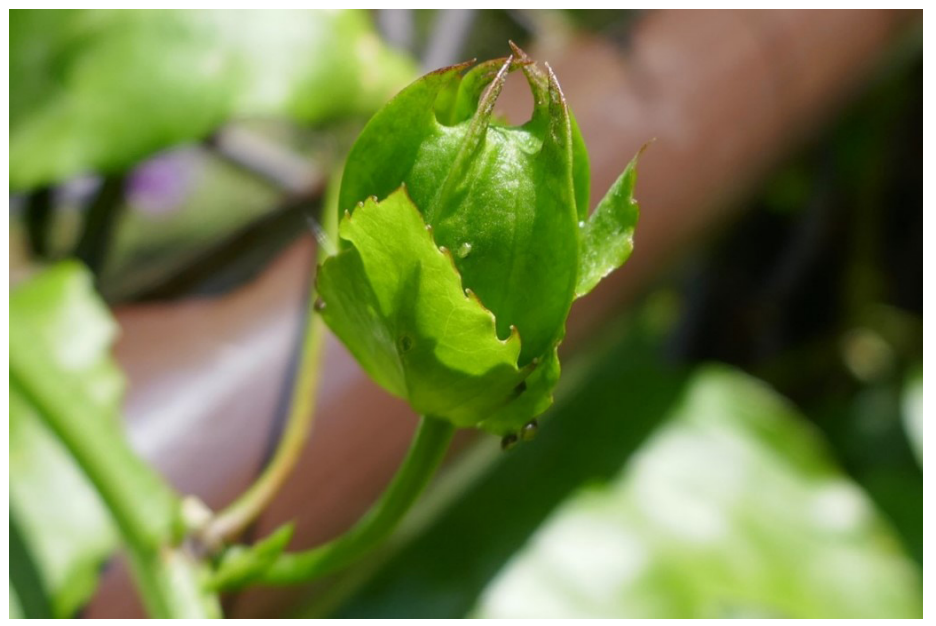

Figure 7. Flower bud nearing blossoming. Credits: Mark Bailey, UF/IFAS 


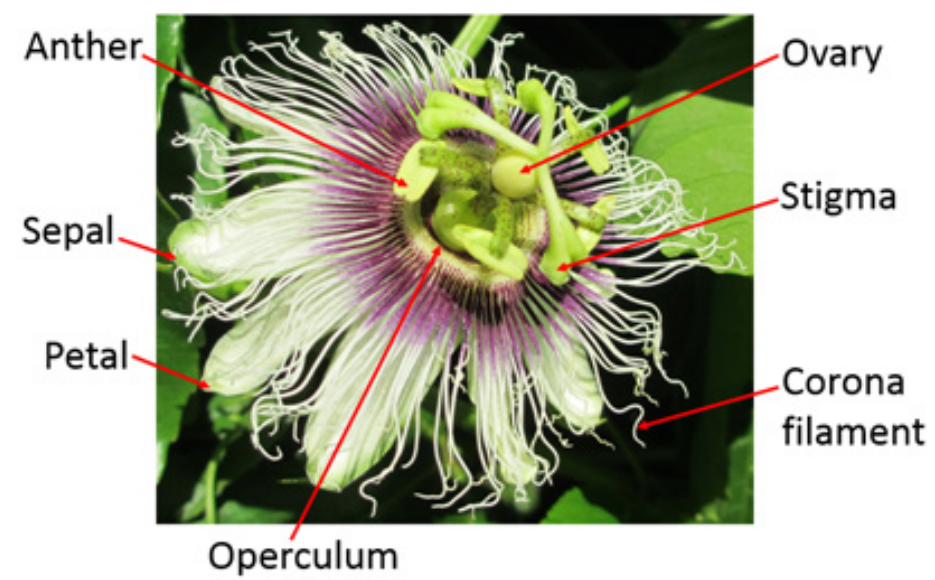

Figure 8. Diagram of flower anatomy.

Credits: Mark Bailey, UF/IFAS

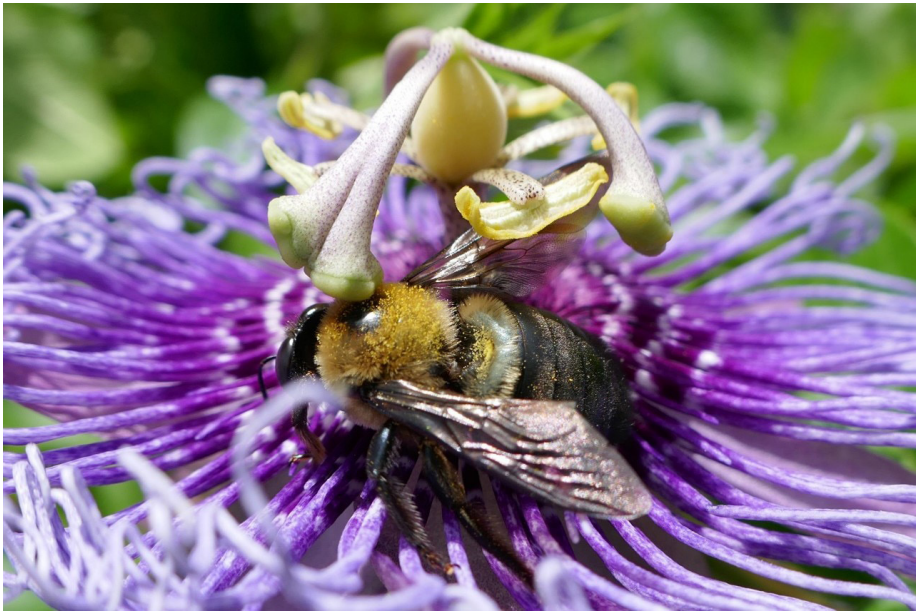

Figure 9. Xylocopa virginica (eastern carpenter bee) with pollen on passion flower (P. incarnata).

Credits: Mark Bailey, UF/IFAS

Fruit Morphology: Flowers emerge on new growth and will only produce a fruit if pollinated. The quantity of pulp is determined largely by pollination quality. The fruit originates from the ovum of the flower. As the immature green fruit grows, remnants of the flower sepals and petals may remain (Figure 10). Mature fruit ripen into colors ranging from dark purple or burgundy to yellow (Figure 11). The pepo-type rind surrounds a white pith, which together is botanically a berry filled with pulp covering black seeds. The pulp is composed of membranous sacs, called arils, filled with orange-yellow juice (Figure 12). Mature fruit are typically about $2 \frac{1}{2}-3$ inches long and about $2 \frac{1}{4}$ inches wide and may be egg-shaped to round.

\section{Passion Fruit Cultivars}

There are numerous local selections of passion fruit in Florida, with most of them being hybrids between yellow and purple types (e.g., cultivars 'Panama Red', 'Purple Possum', and 'Bounty'). Commercial producers have typically selected their own superior seedlings for scions that they vegetatively propagate via rooted cuttings or that they graft onto a rootstock. A passion fruit cultivar can be evaluated for characteristics that include fruit size, appearance, disease resistance, quantity of pulp or juice, pulp-to-skin ratio, flavor, sugar and acid concentration, and aromatic qualities. There is limited information about cultivar characteristics, although what is known is listed below.

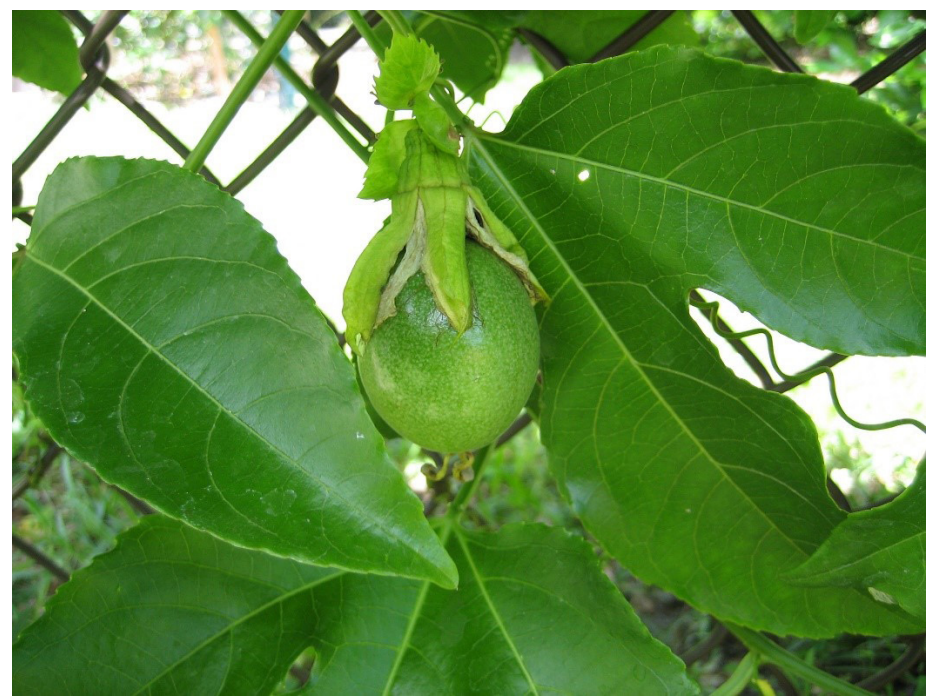

Figure 10. Purple passion fruit, immature, with flower remnants. Credits: Mark Bailey, UF/IFAS

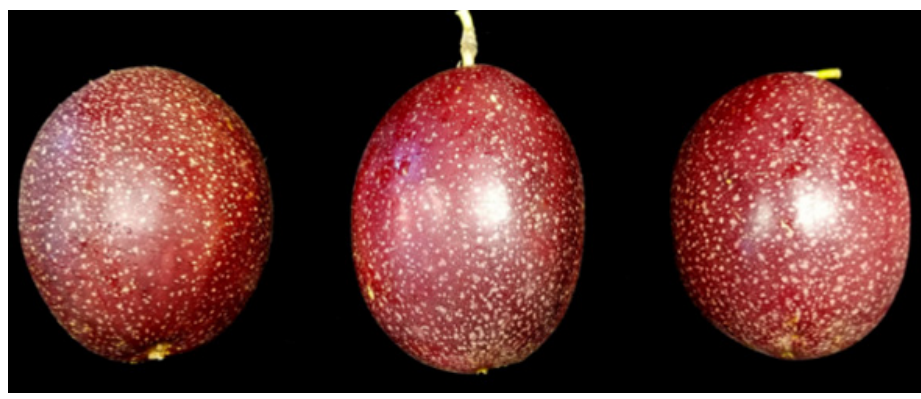

Figure 11.'Panama Red' fruit. Credits: Alan Chambers, UF/IFAS

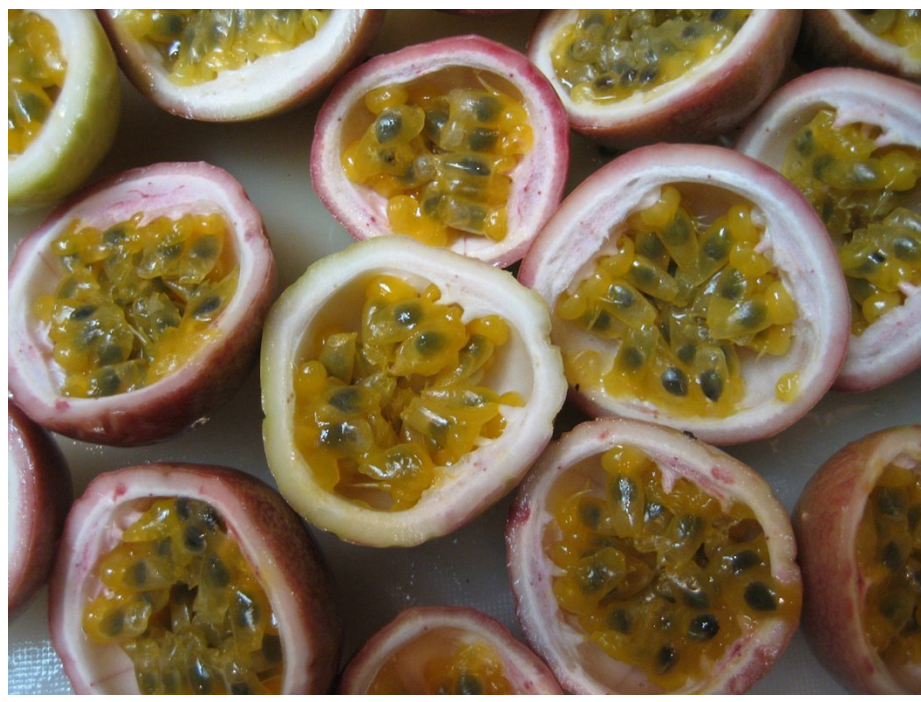

Figure 12. Passion fruit cross section, showing juice-filled arils and black seeds.

Credits: Mark Bailey, UF/IFAS 


\section{'Possum Purple'}

A seedling selection from Possum Trot Nursery is the most widely grown and propagated cultivar in south Florida (Figure 14). The flowers are self-compatible. The peel has a medium-dark purple color with numerous light dots covering the surface. Fruit are 2.5 to 3.5 inches long and $\sim 2$ inches in diameter. The fruit have a pleasant aroma and the juice has a sweet, moderately strong flavor. Flowering to harvest takes 70-75 days.

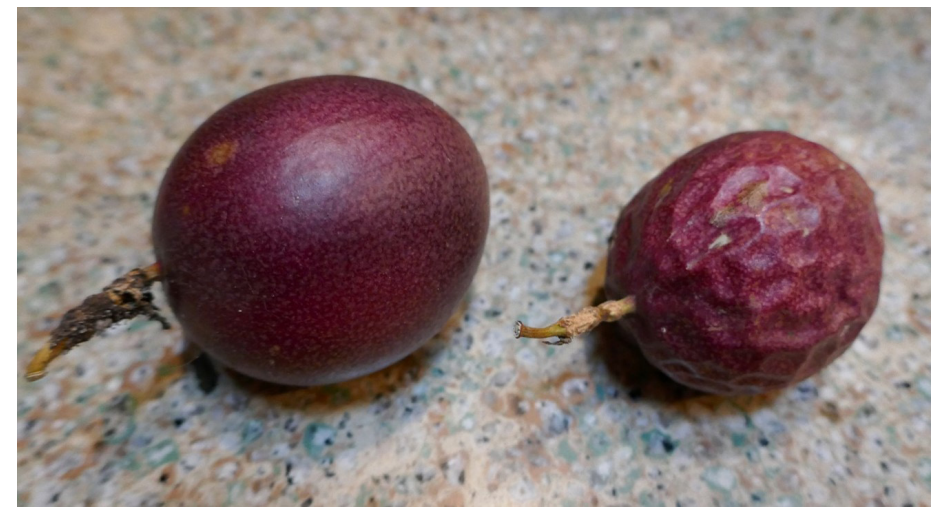

Figure 13. 'Purple Possum' fruit with characteristic wrinkled fruit on the right.

Credits: Mark Bailey, UF/IFAS

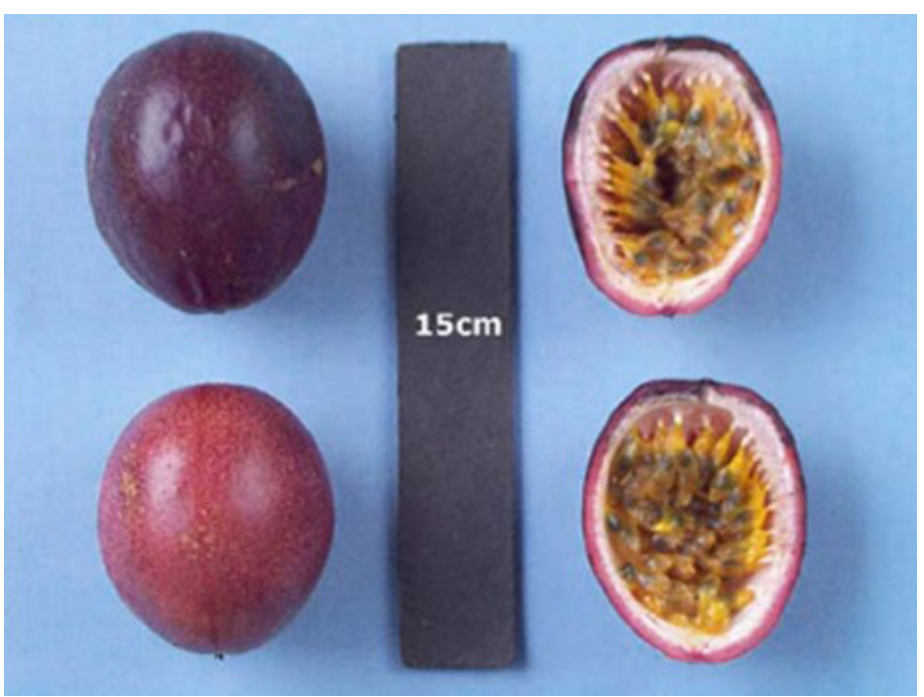

Figure 14. 'Possum Purple' passion fruit.

Credits: Jonathan Crane, UF/IFAS

\section{'Panama Red'}

As the name suggests, 'Panama Red' has a red peel color when ripe. It is oval in shape. It is likely selected by Australian producers for higher yields. The fruit can be larger than 'Possum Purple' and have a similar flavor profile.

\section{'Sweet Sunrise'}

The 'Sweet Sunrise' variety is a yellow type with fruit about the size of a baseball. It is currently sold by nurseries in southern Florida (Figure 15).

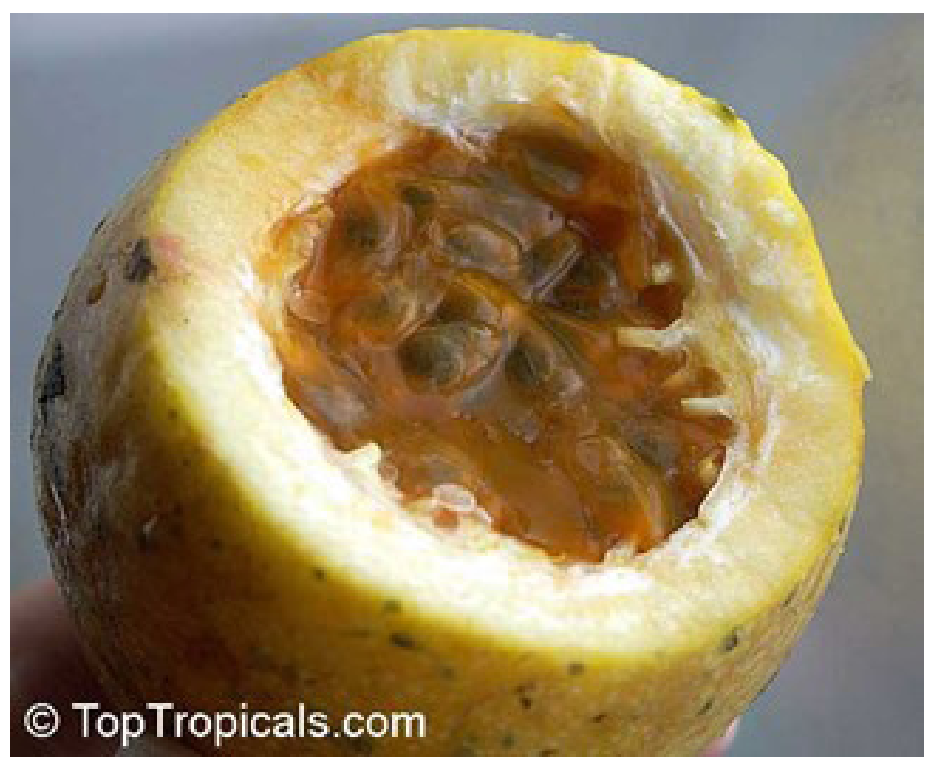

Figure 15. 'Sweet Sunrise' passion fruit.

Credits: Top Tropicals

\section{'Whitman Yellow'}

A seedling selected by William Whitman, a long-time and well-known tropical fruit enthusiast intimately involved in tropical fruit culture in south Florida (Figure 16).

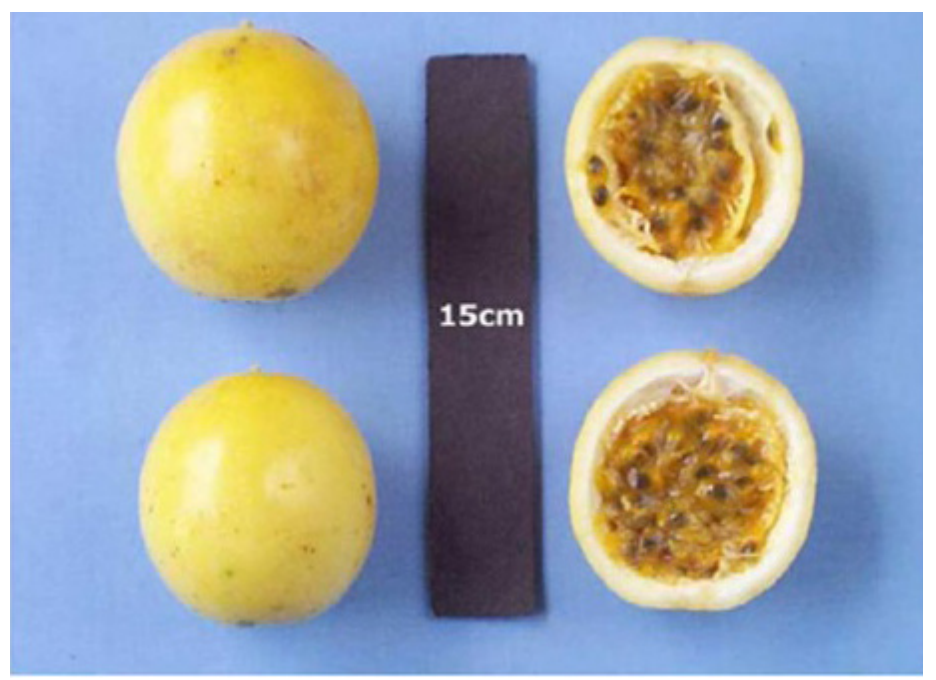

Figure 16. 'Whitman Yellow' passion fruit.

Credits: Jonathan Crane, UF/IFAS

Additional cultivars from Hawaii and Australia may not be currently available in south Florida. Those of interest include 'Australian Purple, 'Don's Choice, 'Frederick', 'McGuffy', 'Misty Gem,' 'Nellie Kelly', 'Panama', 'Pandora', 'Pink Cheek,' 'Pratt Hybrid,' 'Red Flemenco', 'Red Rover', 'Sweetheart,' 'Tas Black', 'Toms Special', and 'Waimanalo Selection'. Yellow cultivars include 'Kapoho Selection', 'Mike's Choice,' 'Panama Gold', 'Sevcik Selection,' 'University Round Selection, 'University Selection No. B-74', 'Whitman', and 'Yee Selection'. 


\section{Culture and Management}

Propagation: Passion fruit may be propagated from cuttings, micropropagation, or fresh seed. Only disease-free planting material should be used, especially due to the presence of persistent viruses. If propagated from seeds, they should be as fresh as possible and kept in warm, humid conditions to induce germination. While fresh seeds will have a higher germination rate than older seeds, they still have relatively low germination rates compared to other crops. Germination can be aided by scarifying the seed coat, nicking the edge of the seed using a sharp blade, and soaking overnight in water. Seeds can be sown in flats or pots of clean soil or growing media and kept moist. High-humidity conditions are best, which can be aided by covering the growing containers with plastic or humidity domes. If kept warm (about $85^{\circ} \mathrm{F}$ ), seeds typically germinate in a week and a half to three weeks. After germination, young plants should be kept in partial shade rather than direct sunlight, which will burn the young plants. Transfer young plants from a partial shade to partial sun for several days prior to planting in full sun.

Passion fruit can be propagated by cuttings from productive healthy plants, selected carefully to avoid propagating virus-infected plants (Figure 17). This can be done by cutting off a portion of a healthy vine with active foliage. To increase success, use at least two nodes; up to four can be included per cutting. Remove all but the top leaf, making note of which end is the bottom (i.e., by the direction of vine growth). The bottom of the cutting can be dipped in a rooting hormone and then planted about 2-4 inches deep in clean growing media. It should be kept moist (with humidity domes, plastic bags, or intermittent misting) in indirect light and provided with regular moisture to the soil/growing media. Under optimal conditions, cuttings may be ready for planting in three or four months. Cuttings should be kept insect-free to reduce the likelihood of viral infections.

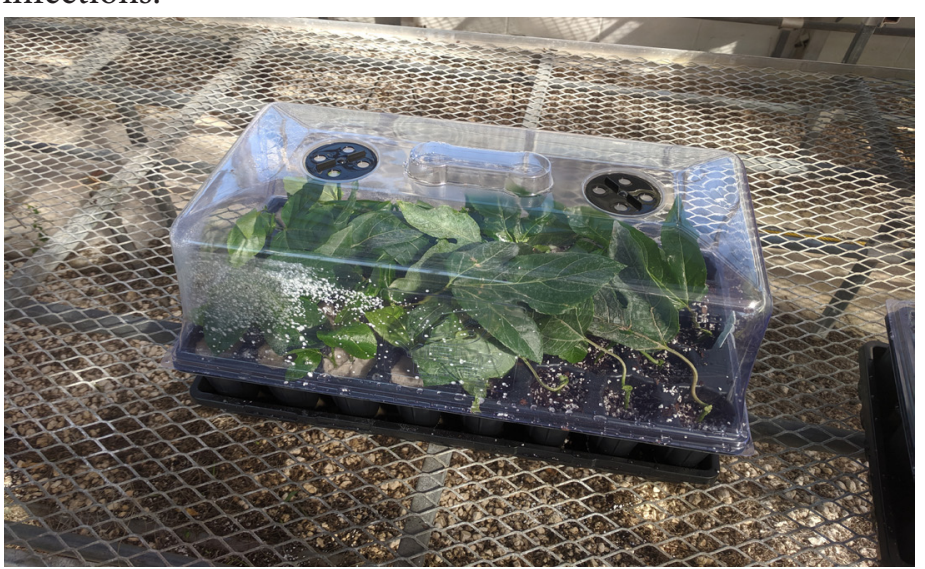

Figure 17. P. edulis cuttings in a deep well flat covered by humidity dome. Credits: Joshua Anderson, UF/IFAS
Grafting: Purple passion fruit can be grafted onto a yellow passion fruit rootstock in an effort to reduce disease problems that affect the root system of susceptible cultivars. Seedlings of both stock and scion plants should be about 18 inches long and have a stem diameter of approximately $1 / 4$ inch when selected for grafting. Scions should be about 3-4 inches long and contain at least 2 nodes when cut for the graft. The stock should be cut off 10-12 inches above the soil line. Several methods of grafting can be accomplished using a cleft, including whip-and-tongue, saddle, and veneer grafts. The most important aspect of grafting is to align the vascular cambia and hold the graft firmly in place by wrapping with parafilm or grafting tape. Keep the grafted plant watered in a warm, indirect-light location for 10-14 days or until the union takes. The wrapping can be removed when the graft has fully healed.

Location: Passion fruit grow best in full sun or a location where they can reach full sun after climbing. Passion fruit vines should be planted in well-drained soils and will tolerate near-neutral to alkaline ( $\mathrm{pH}$ 6-7.5) conditions, but slightly acid soils are best.

Planting, infrastructure, and irrigation: In areas with potentially freezing or cold temperatures $\left(<50^{\circ} \mathrm{F}\right)$, young plants may be planted in early spring when the chance of frost is over. In areas with warm to hot temperatures, plants may be planted anytime (temperatures $<90^{\circ} \mathrm{F}$ ) as long as irrigation is available during dry periods.

For home landscape plantings, a simple but strong fence or trellis that can withstand high winds when covered with a vine may be used. For commercial production, there are numerous trellis designs and configurations. A common method is a vertical trellis with rows spaced 10 to 15 feet apart. Spacing between plants in the row varies between 6 and $10 \mathrm{ft}$. Rows should be planted north-south to maximize exposure to sunlight. Ground cover, plastic mulch, or conventional mulch can be used to suppress weeds and maintain soil moisture. An alternative to planting directly into native soil is to use grow bags, which allow for custom-blended media that is disease- and nematode-free. Typically, these container-grown plants are placed on a stand (e.g., cinderblocks) to facilitate drainage and avoid direct contact with the soil. In home landscapes, passion fruit vines may be irrigated with a small low-aspect sprinkler or with installation of a drip system. It is helpful but not required to have timers programmable with climate information and a rain gauge to manage the system so as to minimize watering frequency and quantity. 
Commercial plantings use drip lines under plastic mulch or microsprinkler irrigation to minimize water usage and maintain maximum plant productivity. Passion fruit need small but frequent irrigation to ensure that adequate soil moisture is maintained, though not saturated. Soil moisture probes (e.g., tensiometers, capacitance probes) and weather monitoring will improve irrigation scheduling, minimize irrigation rates, and reduce the chance of leaching water and nutrients below the root zone.

Training and Pruning: After new vines have been planted, they should be trained along trellising wires. Afterward, the vines will naturally attach to anything the tendrils can wrap around (Figure 18 and 19). Depending upon the trellis design, vines should be trained to grow in a manner that maximizes the canopy surface area. An option is a "curtain" training system, in which one main stem reaches to the top support wire, with vines spreading horizontally and then drooping down like a curtain to fill in the open space below. Vines should be pruned in late winter when they are not actively growing. Use a $10 \%$ bleach solution or quaternary ammonium to disinfect cutting tools between each plant to avoid spreading disease. Over time, if left unmanaged, the new vine growth may become dense and cover older vine growth that loses its leaves, forming a thatch-like canopy composed of dead leaves. This can be a source of fungal diseases that negatively affect new leaves and fruit quality. Vines can be pruned back to the main vine or healthy branches from the main vine. All dead and weak stems should be pruned out and pruned back to vigorous stems so that they can resume healthy, active growth in early spring. A good time to make the first fertilizer application is after pruning.

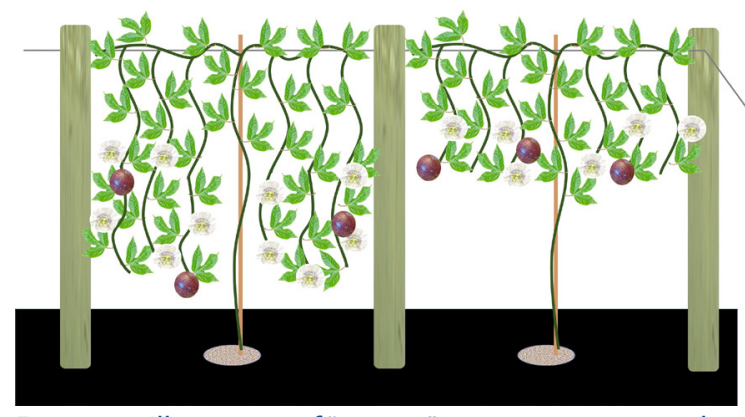

Figure 18. Illustration of "curtain" training on a vertical trellis; older stage on left.

Credits: Josh Anderson, UF/IFAS

\section{Environmental Stresses}

Cold Stress: Optimum temperatures for growth and production vary by passion fruit species and type (Menzel and Simpson 1994). In general, temperatures between $\sim 65^{\circ} \mathrm{F}$ and $90^{\circ} \mathrm{F}$ are best for vine growth and fruit production; temperatures outside this range may result in reduced growth, flowering, pollen viability, and fruit production. Mature vines with adequate foliage may tolerate temperatures several degrees below freezing but may be killed to the ground with prolonged exposure to freezing $\left(32^{\circ} \mathrm{F}\right)$ and subfreezing (low to mid 20s) temperatures (Campbell et al. 1977). Passion fruit vines may also experience chilling injury when temperatures are below $\sim 59^{\circ} \mathrm{F}$ but above $32^{\circ} \mathrm{F}$ (Menzel and Simpson 1994). Experience with cold protection of vines suggests that high-insulation wraps (e.g., high $\mathrm{R}$-value fiberglass batting insulation) wrapped around the base of the vine may protect this area from freeze damage; new shoots would grow from this area post-freeze event. Insulating wraps should be removed post-freeze event.

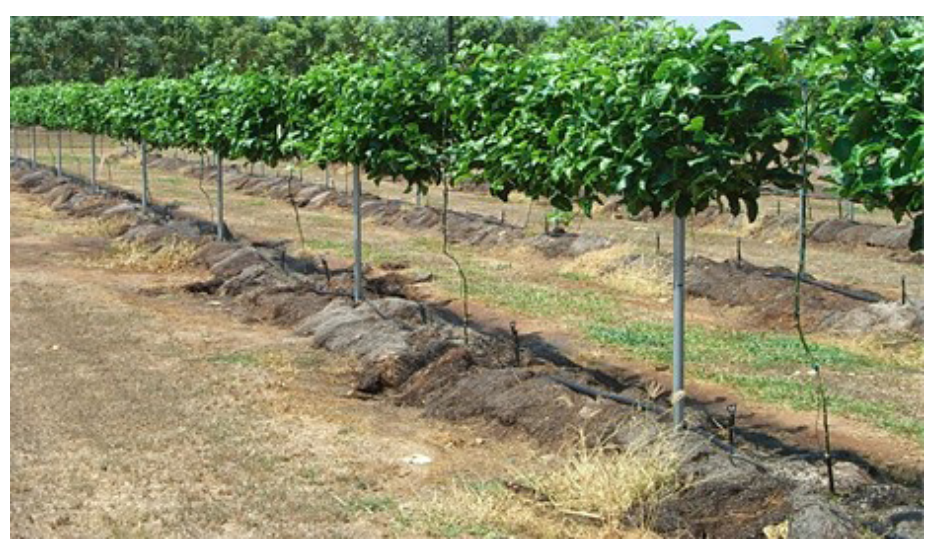

Figure 19. Training passion fruit plant on a vertical trellis. Credits: Ali Sarkhosh, UF/IFAS

A properly designed high-water-volume irrigation system may protect vines from freezing. Typically, high-volume $360^{\circ}$ rotating sprinklers placed above the trellis at a spacing to allow for complete water coverage of the vines are used and have successfully protected vines during freeze events in south Florida (J. H. Crane, personal communication). The systems need to be properly installed and maintained, turned on when field temperatures reach $\sim 36^{\circ} \mathrm{F}$, and left on until wet bulb temperatures reach above $32^{\circ} \mathrm{F}$ the next day. Please contact your local UF/IFAS Extension agent for more information.

Drought Stress: Passion fruit vines and fruit production are sensitive to dry soil conditions. Drought stress results in reduced passion fruit vine growth, flowering, fruit set, and fruit size (Menzel and Simpson 1994; Turner et al. 1996). Recent research has shown that drought conditions also makes plants more susceptible to the soilborne diseases caused by Fusarium fungal species (Lima et al. 2019). Severe drought stress results in defoliation, fruit drop, and vine death.

Fertilizer Guidance: During the first year, a young vine should be fertilized to encourage maximum growth of the roots and vines (Table 1). Maximum fruit production 
usually begins after a full year of growth. Common fertilizers, such as $10-10-10$ or 8-3-9, may provide adequate nutrients such as nitrogen, phosphorus, and potassium. It is important to also provide secondary nutrients and micronutrients to maximize plant health and fruit quality. Secondary nutrients include magnesium and sulfur, and micronutrients include boron, nickel, manganese, copper, zinc, and iron. Nutrients may be applied either as fertigation (liquid fertilizer applied through irrigation lines), as a granular fertilizer, or via foliar feeding. If granular fertilizer is used, small amounts $(0.25 \mathrm{lb} /$ plant to $1 \mathrm{lb} /$ plant $)$ should be made from late winter through fall on 4 - to 6-week intervals (Table 1). These intervals can last through July in northern Florida, while they can continue through October in southern Florida. For vines growing in high-pH soils $(>7)$, secondary nutrients and micronutrients may be applied to foliage or in chelated form to the soil. Chelated iron applications are important for vines growing in high-pH calcareous soils. A chelate such as Sequestrene $138(6 \%$ Fe-EDDHA) is a good choice; mix the powder with water and drench near the base of the plants 2 to 4 times per year. After the first year of growth, the amount of nitrogen fertilizer should be substantially reduced to facilitate flowering rather than excessive vegetative growth.

\section{Flowering, Pollination, and Fruit}

In south Florida, passion fruit flower and fruit from spring through fall/early winter, depending upon the cultivar (Figure 20). In north central Florida, flowering typically occurs in the spring, and fruit mature in midsummer. Pollination is essential for fruit production. Purple passion fruit flowers are self-fertile, while many purple-yellow hybrids may or may not be self-fertile. Yellow passion vines are not self-fertile and require pollen from a compatible vine that is genetically different. If using self-incompatible cultivars of passion fruit, it is suggested to plant two different cultivars in the same area to encourage pollination and fruit set. While carpenter bees are commonly found in north and central Florida, they are rarely observed in south Florida. Hand pollination with a clean cotton glove or paintbrush is a labor-intensive but effective way to ensure fruit production. The time from flowering to harvest is generally $70-75$ days.

\section{Harvest and Storage}

A one-year-old passion fruit vine can be expected to produce between 5 and $15 \mathrm{lb}$ of fruit per plant. Peak production is during midsummer through fall throughout Florida. Total passion fruit yield for an acre ranges from 2,200 lb to 4,400 lb per acre (Knight and Sauls 1994), which corresponds to 18,000 to 35,000 fruit. Once the fruit are ripe they will drop to the ground, which does not damage the thick-skinned fruit (Figure 20 and 21). While fruit can be picked directly off the vine, it is difficult to assure the fruit is fully ripe on the interior. Nonripe fruit have inferior aroma and flavor. Dropped fruit should be regularly collected to maintain postharvest quality. The fruit remains firm when ripe and over time will wrinkle as the water is lost mostly from the peel. Though still edible, this wrinkling may decrease marketability (Figure 13).
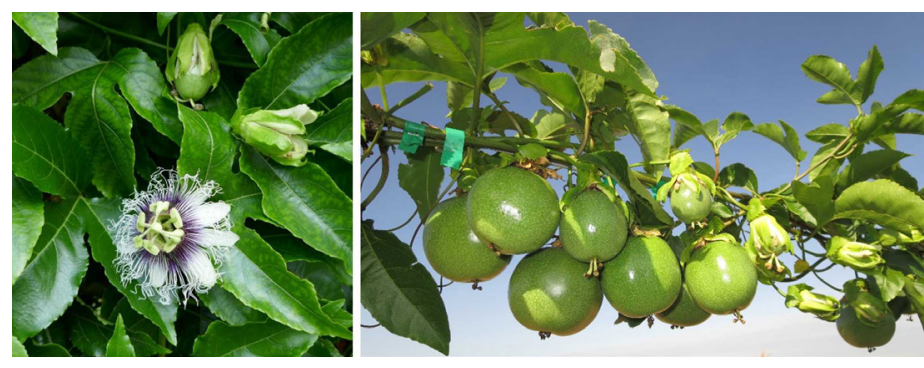

Figure 20. Flower and fruit development. Credits: Mark Bailey and Ali Sarkhosh, UF/IFAS

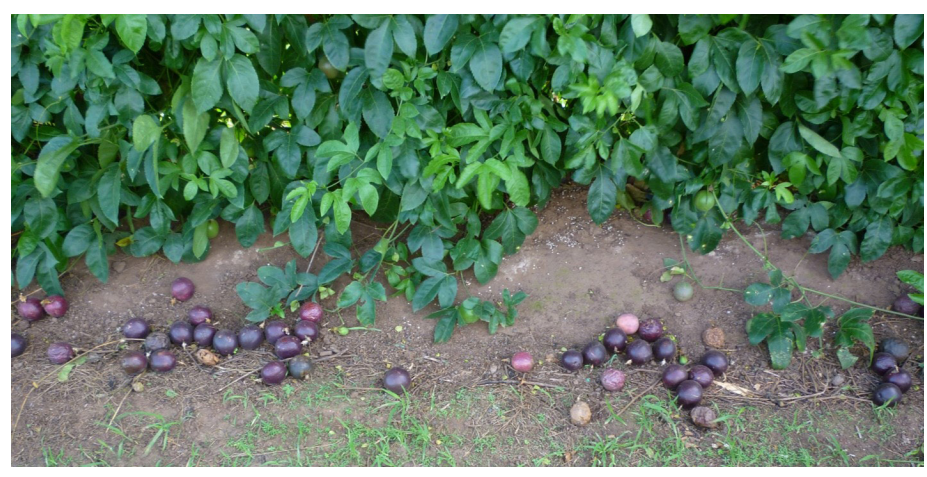

Figure 21. Ripened passion fruit dropped at the ground. Credits: Ali Sarkhosh, UF/IFAS

Flower residue will often remain on the stem of the fruit and can be easily removed. In general, fresh fruit may be stored for up to two or more weeks in plastic bags at $41^{\circ} \mathrm{F}-$ $54^{\circ} \mathrm{F}$ and $85 \%-90 \%$ relative humidity (Bora and Narain 1997; Paull and Chen 2016). Ripe fruit dropping on the ground may raise concerns of cross-contamination; growers should check with buyers regarding their expectations for safe handling practices.

\section{Pests and Diseases}

Passion fruit are affected by several insect pests, mites, nematodes, and fungal and viral plant pathogens, which can cause significant harm to the plants and fruit (Figure 22). The larvae of several butterfly (Lepidoptera) species can completely defoliate passion fruit vines if left uncontrolled.

Stink bugs may occasionally probe (puncture) the fruit and cause minor damage to the fruit crop. Spider mites also can cause serious defoliation leading to death if vines are in 
areas with few natural predators of the mites (Figure 23). A number of insecticides and fungicides are registered for use on commercial passion fruit. However, it is critical which materials are chosen to apply and that the timing of those applications does not kill native pollinators and honeybees. Please contact your local UF/IFAS Extension office for more information and guidance.

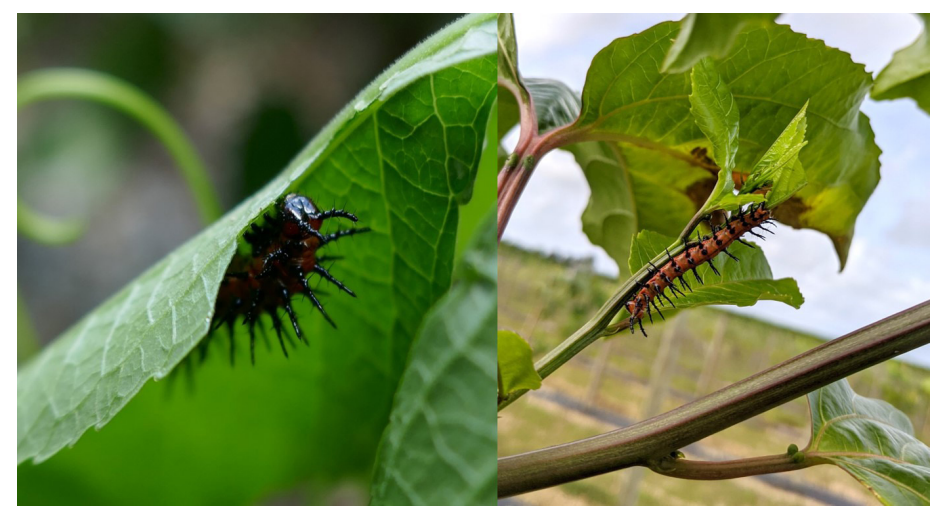

Figure 22. Gulf fritillary caterpillar feeding on leaf.

Credits: Mark Bailey and Joshua Anderson, UF/IFAS

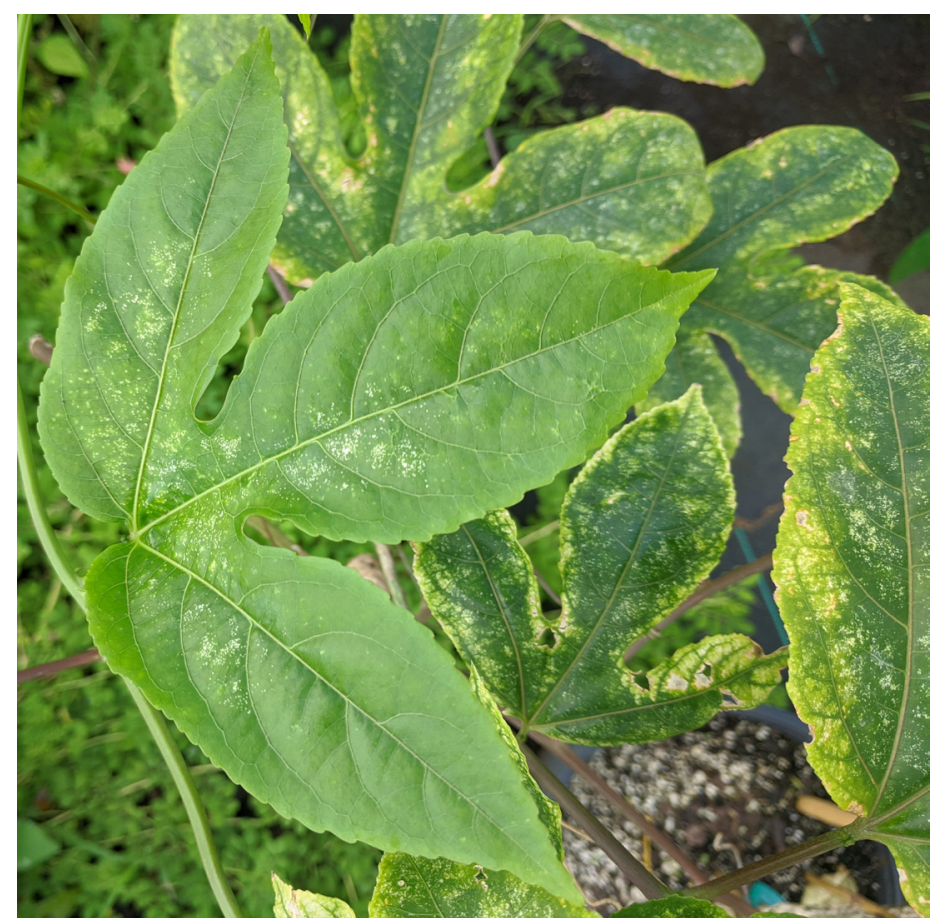

Figure 23. Spider mite damage. Notice the recent damage on younger leaf compared to older damage.

Credits: Joshua Anderson, UF/IFAS

Parasitic nematodes (microscopic worms) are more likely to attack the root systems of purple passion fruit than yellow passion fruit. Symptoms include wilting of the plant, poor growth, and stunted or malformed roots. In Florida, purple varieties are sometimes grafted onto yellow varieties to help mitigate some fungal and nematode root damage.
There are several significant pathogens that can damage or kill the entire plant and harm fruit quality and production (Figure 24, 25, and 26). A principal pathogen suspect in passion fruit plantings in south Florida is Fusarium solani, canker (Ploetz 1991). Symptoms of canker include sudden wilting of leaf canopy, which becomes chlorotic and remains attached along with affected fruit. Additionally, dying tissue around the base of the stem may eventually girdle the entire stem at the soil level, which can be associated with root rot, swelling of stem at the canker, and adventitious root growth. Discolored vasculature is visible usually less than $2 \mathrm{ft}$ from the canker (Manicom et al. 2003).

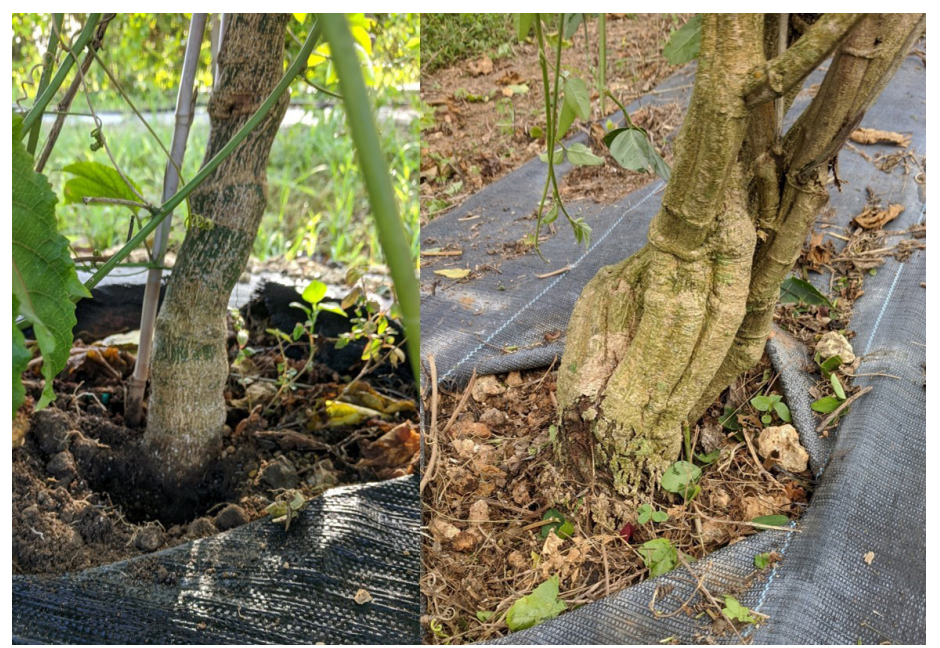

Figure 24. Comparing a healthy stem of a yellow passion fruit rootstock, left, to a yellow seedling with canker, right, where there is swelling and outside bark dying. Credits: Joshua Anderson, UF/IFAS

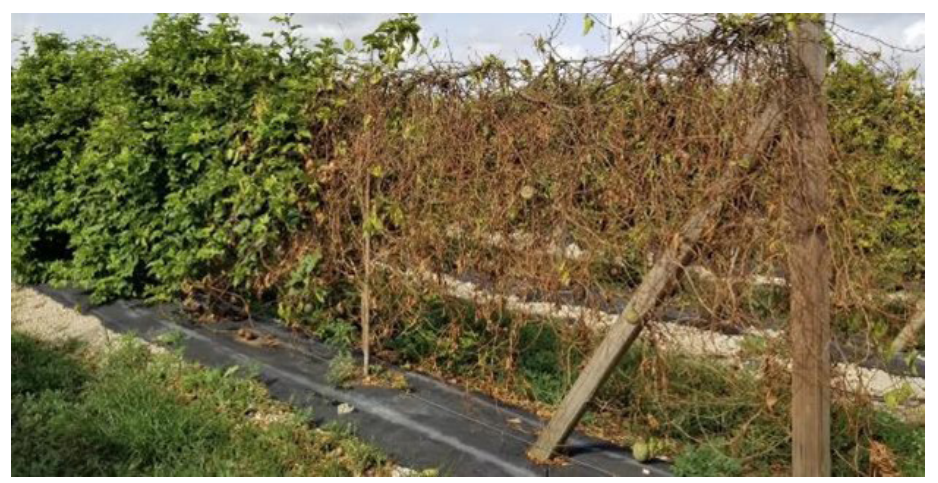

Figure 25. Vine death resulting from pathogen attack of the root system.

Credits: Alan Chambers, UF/IFAS

The fungal pathogen Alternaria may attack the leaves and fruit, causing leaf and fruit spots. Phytophthora (fungallike) pathogens feed on roots and the basal stem of plants, causing crown or root collar rot, defoliation, and death, preceded by a thickening of the root collar, mild chlorosis sometimes appearing as a leaf burn/scorch, and wilt (Fischer and Rezende 2008). Fruit are also affected with gray to green water-soaked lesions. Controlling soilborne 
diseases of passion fruit is further complicated by soils that do not drain well. In cases where vines have died or are severely affected by pathogens, it is best to remove the entire plant and replace it with a new, healthy plant. If the plant died from a soilborne pathogen, it is best not to plant in the same location in order to prevent recurrence of the pathogen.

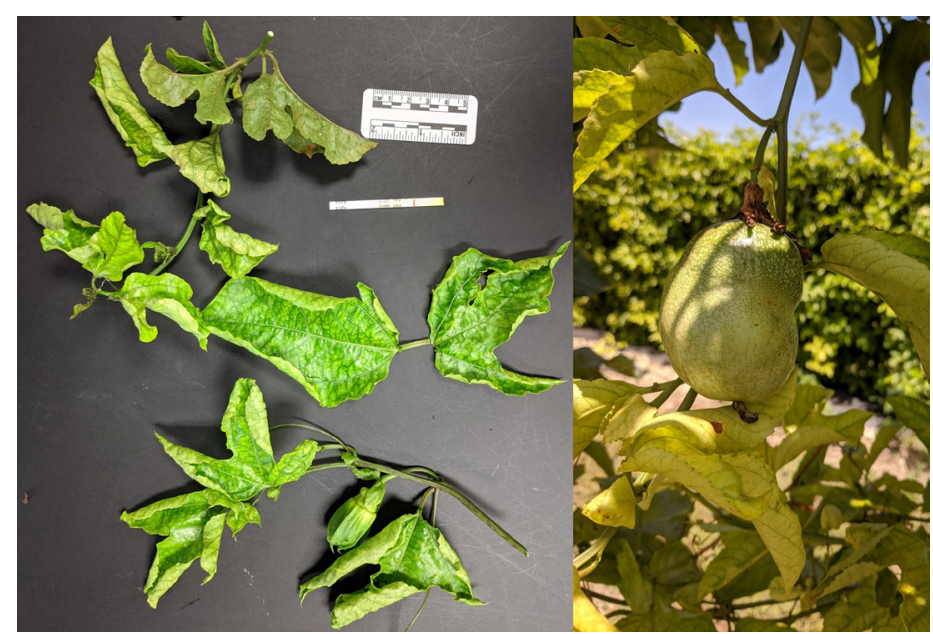

Figure 26. Potyvirus symptoms: left, leaf mosaic, mottling, curling, and deformation; right, deformed fruit with chlorotic leaves.

Credits: Joshua Anderson, UF/IFAS

Plants in the nursery should be off the ground, where they could be exposed to nematodes or fungal pathogens. If vines are growing on a trellis, it is important to not allow thatching (the buildup of dead leaves and vine) to occur because this will greatly increase the chances of disease development on leaves and especially on fruit. In cases where fungal pathogens of the leaves and fruit are expected, judicious use of registered fungicides can be applied preventively. Please contact your local UF/IFAS Extension office for further information.

Some viruses (e.g., woodiness virus) can be major limiting factors for establishing and growing passion fruit vines. Virus infections are noncurable in field conditions and are considered a major (if not the most) limiting factor in passion fruit production worldwide. Passion fruit viruses are a considerable threat in Florida (Baker et al. 2014; Elliott et al. 1991; Fischer and Rezende 2008). The potyviruses species (e.g., Cowpea aphid-borne mosaic virus, CABMV) cause woodiness or passion fruit woodiness disease (Nascimento et al. 2006). The symptoms include defoliation, distorted leaves with mosaic or mottling patterns, and hardened (i.e., woody), deformed fruit (Figure 26). There are no reported resistant genotypes to CABMV infections (Costa et al. 2020). Viruses are generally transmitted by aphids but also through infected planting material (e.g., cuttings), and some viruses may be transmitted by seed. It is essential to use clean seeds or new plants that are disease-free. Potential propagation material should be tested for viruses prior to their use. Prior to starting to grow a new plant or planting, all virus-infected plants in the area should be rogued. If the disease pressure is high in a particular area, new planting sites isolated from the older sites is advisable.

\section{Food}

Passion fruit juice is a source of dietary fiber, ascorbic acid (vitamin C), carotenoids (vitamin A), riboflavin, iron, potassium, and niacin (Percival and Findley 2007; USDA ARS 2020) (Figure 27). Passion fruit is famous for its pleasantly aromatic qualities and rich, acidic, and fruity flavor. The fruit pulp can be consumed raw along with the crunchy seeds. The undiluted juice has a strong flavor and is an excellent additive for other juices and drinks. It can also be used in foods such as jams, jellies, frosting, ice cream, and pastry fillings.

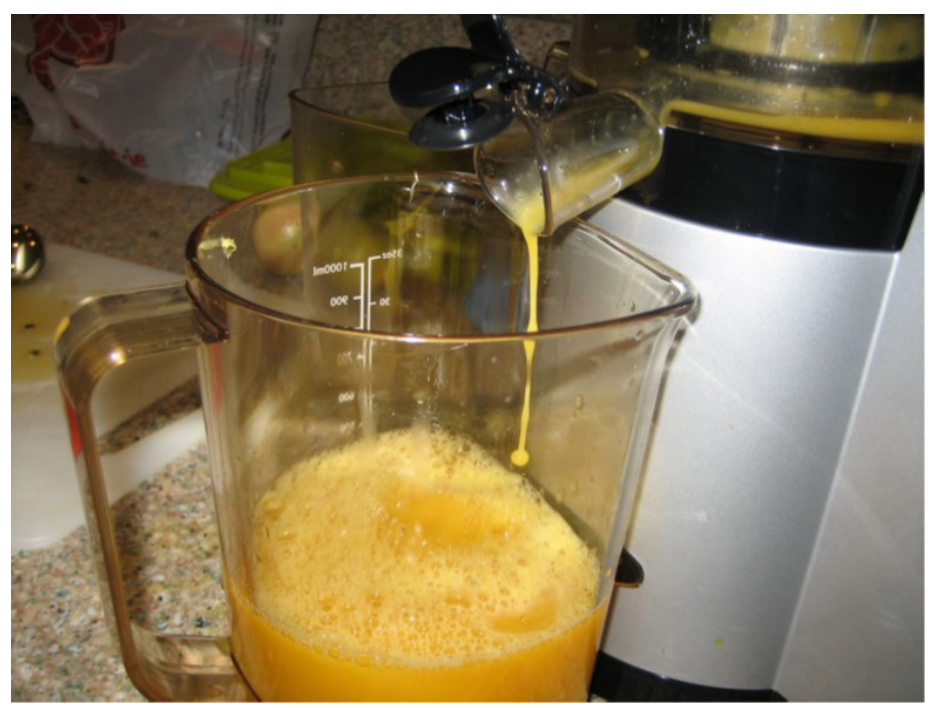

Figure 27. Extracting passion fruit juice using a juicer. Credits: Susan Bailey, UF/IFAS

\section{Marketing}

Passion fruit is grown in most equatorial regions of the world and often where an established market exists. It is sold as a commodity for its juice, concentrates, and raw fruit. Florida, California, and Hawaii make up the majority of domestic fresh-fruit production, though most fresh fruit are imported to the United States. Fruit on the wholesale market are reported to range from about $\$ 0.75-\$ 2.00$ per fruit depending upon market conditions and other variables (USDA Agricultural Marketing Service 2021). Fruit can be marketed individually, in clam shells, or in flats of a dozen or multiples of a dozen. Retail selling options include by count or by weight. Fruit are also sold direct to customers through farmers markets and online, shipped to buyers, or wholesale for retail markets. 


\section{Literature Cited}

Altendorf, S. 2018. "Minor Tropical Fruits: Mainstreaming a Niche Market." FAO Food Outlook, July 2018. Accessed August 29, 2020. http://www.fao.org/3/ca0239en/ CA0239EN.pdf

Baker, C. A., A. Jeyaprakash, C. G. Webster, and S. Adkins. 2014. "Viruses Infecting Passiflora Species in Florida." Florida Dep. Agric. Consum. Serv. Plant Pathol. Circ.

Baumgartner, J. G. 1987. “Nutrição e adubação.” In Maracujá, edited by C. Ruggiero, 86-96. São Paulo, Brazil: UNESP (São Paulo State University).

Bernacci, L. C., M. D. Soares-Scott, N. T. V. Junqueira, I. R. da S. Passos, and L. M. M. Meletti. 2008. "Passiflora edulis Sims: The Correct Taxonomic Way to Cite the Yellow Passion Fruit (and of Others [sic] Colors)." Rev. Bras. Frutic. 30 (2): 566-576. https://doi.org/10.1590/ s0100-29452008000200053

Bora, P. S., and N. Narain. 1997. "Passion Fruit." In Postharvest Physiology and Storage of Tropical and Subtropical Fruits, edited by S. K. Mitra, 375-386. New York, NY: CAB International.

Campbell, C. W., R. J. Knight, Jr., and N. L. Zareski. 1977. "Freeze Damage to Tropical Fruits in Southern Florida in 1977." Proc. Fla. State Hort. Soc. 90:254-257.

Costa, A. P., I. Nogueira, J. R. Peixoto, and L. E. B. Blum. 2020. "Screening of Sour Passion Fruit for Reaction to Bacterial Spot and Passion Fruit Woodiness Disease." J. Agric. Sci. 12 (2): 130-137. https://doi.org/10.5539/jas. v12n2p130

Elliott, M. S., F. W. Zettler, and J. H. Crane. 1991. "Surveys for Viruses of Passiflora spp. Which Threaten the Passionfruit Industry in South Florida." Proc. Fla. State Hort. Soc. 104:49-50.

Fischer, I. H., and J. A. M. Rezende. 2008. "Diseases of Passion Flower (Passiflora spp.).” Pest Technology 2 (1): 1-19.

FLEPPC. 1999. "1999 List of Invasive Plant Species." Florida Exotic Pest Plant Council. Accessed August 30, 2020. https://www.fleppc.org/list/list.htm

FLEPPC. 2019. "2019 List of Invasive Plant Species.” Florida Exotic Pest Plant Council. Accessed August 29, 2020. https://www.fleppc.org/list/list.htm
Knight, R. J. 1972. "The Potential for Florida of Hybrids between the Purple and Yellow Passionfruit." Florida State Hortic. Soc. 85:288-292.

Knight, R. J., and H. F. Winters. 1962. "Pollination and Fruit Set of Yellow Passionfruit in Southern Florida." Florida State Hortic. Soc. 75:412-418.

Knight, R. J., Jr. and J. W. Sauls. 1994. The Passion Fruit. HS60. Gainesville: University of Florida Institute of Food and Agricultural Sciences. https://ufdc.ufl.edu/ IR00003395/00001

Lima, L. K. S., O. N. de Jesus, T. L. Soares, S. A. S. de Oliveira, F. Haddad, and E. A. Girardi. 2019. "Water Deficit Increases the Susceptibility of Yellow Passion Fruit Seedlings to Fusarium Wilt in Controlled Conditions." Sci. Hortic. 243:609-621. https://doi.org/10.1016/j. scienta.2018.09.017

Manicom, B., C. Ruggiero, R. C. Ploetz, and A. de Goes. 2003. "Diseases of Passion Fruit." In Diseases of Tropical Fruit Crops, edited by R. C. Ploetz, 413-441. Cambridge, MA: CABI. https://doi.org/10.1079/9780851993904.0413

Menzel, C. M., G. F. Haydon, V. J. Doogan, and D. R. Simpson. 1993. "New Standard Leaf Nutrient Concentrations for Passionfruit Based upon Season Phenology and Leaf Composition." J. Horticultural Science 68:215-230.

Menzel, C. M., and D. R. Simpson. 1994. "Chapter 10. Passionfruit." In Handbook of Environmental Physiology of Fruit Crops, Vol. II: Subtropical and Tropical Crops, edited by B. Schaffer and P. C. Andersen, 225-241. Salem, MA: CRC Press, Inc.

Nascimento, A. V. S., E. N. Santana, A. S. K. Braz, P. F. Alfenas, G. Pio-Ribeiro, G. P. Andrade, M. G. de Carvalho, and F. Murilo Zerbini. 2006. "Cowpea aphid-borne mosaic virus (CABMV) is Widespread in Passionfruit in Brazil and Causes Passionfruit Woodiness Disease." Archives of Virology 151:1797-1809. https://doi.org/10.1007/ s00705-006-0755-6

Newett, S., J. Daniells, and P. Rigden. 1999. "Growing the Crop." Passionfruit Information Kit Annual Update, Agrilink Series QAL9802. Dept. of Primary Industries, Nambour, Queensland, Australia. 
Paull, R. E., and C. C. Chen. 2016. "Passion Fruit." In USDA-ARS Agric. Handbook Number 66. The Commercial Storage of Fruits, Vegetables and Florist and Nursery Stocks, edited by K. C. Gross, C. Y. Wang, and M. Saltveit, 460-462. Washington, D.C.

Percival, S. S., and B. Findley. 2007. What's in Your Tropical Fruit? FSHN07-08. Gainesville: University of Florida Institute of Food and Agricultural Sciences. https://journals.flvc. org/edis/article/view/116933

Ploetz, R. C. 1991. "Sudden Wilt of Passionfruit in Southern Florida Caused by Nectria haematococca." Plant Dis. 75:1071-1073. https://doi.org/10.1094/pd-75-1071

Queensland Department of Agriculture and Fisheries. 2016. "Managing Passionfruit Plantations Affected by Wet Weather." QLD. Dep. Agric. Fish. 1-4.

Rooney-Latham, S., C. L. Blomquist, and H. J. Scheck. 2011. "First Report of Fusarium Wilt Caused by Fusarium oxysporum f. sp. passiflorae on Passion Fruit in North America." Plant Dis. 95 (11): 1478. https://doi.org/10.1094/ pdis-03-11-0261

Silva, G. S., and M. M. Santos. 2020. "Origin of the Cultivated Passion Fruit Passiflora edulis f. flavicarpa and Genomic Relationships among Species of the Subgenera Decaloba and Passiflor." Plant Biol. 22 (3): 533-540. https:// doi.org/10.1111/plb.13100

Turner, D. W., C. M. Menzel, and D. R. Simpson. 1996. "Short Term Drying of Half the Root System Reduces Growth but No Water Status or Photosynthesis in Leaves of Passion Fruit (Passiflora sp.)." Scientia Horticulturae 65:2536. https://doi.org/10.1016/0304-4238(95)00849-7

Ulmer, T., and J. M. MacDougal. 2004. Passiflora: Passionflowers of the World. Portland, OR: Timber Press.

USDA ARS. 2020. "Passion Fruit Juice, 100\%: Nutrients." FoodData Central. https://fdc.nal.usda.gov/fdc-app.html\#/ food-details/1102755/nutrients

USDA ARS OSU. 2012. Plant Hardiness Zone Map. USDA. gov.
USDA Agricultural Marketing Service. 2021. "Report Results: Passion Fruit." https://www.marketnews.usda.gov/ $\mathrm{mnp} /$ fv-report-top-filters?locName $=\&$ commAbr $=\mathrm{PASSIO}$ NF-V \&commName $=$ PASSION\%20FRUIT\&className $=$ FR UITS\&rowDisplayMax $=25 \&$ startIndex $=1$ \&navClass $=$ FRUI TS\&navType $=$ byComm $\&$ rep Type $=$ termPriceDaily $\&$ type $=t$ ermPrice

Wunderlin, R. P., B. F. Hansen, A. R. Franck, and F. B. Essig. 2020. "Passiflora." In Atlas of Florida Plants. Tampa: Institute for Systematic Botany, University of South Florida. Accessed August 29, 2020. https://florida.plantatlas.usf.edu/ Genus.aspx?id=891 
Table 1. Fertilizer leaf nutrient levels guidance for passion fruit plants in Florida. ${ }^{1}$

\begin{tabular}{|c|c|c|c|c|c|}
\hline Leaf nutrient & nt: Data of youngest ful & expanded (mature & f behind a recent ve & ive flush taken dur & e winter prior to flushing \\
\hline Nutrient & Range & Nutrient & Range & Nutrient & Range \\
\hline $\mathrm{N}$ & $4.25 \%-5.25 \%$ & $\mathrm{Mg}$ & $0.20 \%-0.40 \%$ & $\mathrm{Fe}$ & 100-200 ppm \\
\hline $\mathrm{P}$ & $0.15 \%-0.25 \%$ & $S$ & $0.2 \%-0.4 \%$ & $\mathrm{Cu}$ & $5-20 \mathrm{ppm}$ \\
\hline $\mathrm{K}$ & $2.00 \%-3.00 \%$ & $\mathrm{Mn}$ & $100-500$ ppm & B & 40-60 ppm \\
\hline $\mathrm{Ca}$ & $1.75 \%-2.75 \%$ & Zn & 50-80 ppm & $\mathrm{Na}$ & $<0.15 \%$ \\
\hline & & & & $\mathrm{Cl}$ & $<1.5 \%$ \\
\hline Fertilizer sch & & & & & \\
\hline Months old & Application frequency & $\begin{array}{l}\text { NPK rate/oz per } \\
\text { vine }^{c}\end{array}$ & $\begin{array}{l}\text { NPK rate/lb for } 84 \\
\text { vines }\end{array}$ & $\begin{array}{l}\text { Foliar minor } \\
\text { elements/oz } 0.29 \\
\text { acre }^{d}\end{array}$ & $\begin{array}{l}\text { Soil-applied chelated } \\
\text { iron for } 84 \text { plants (oz) }\end{array}$ \\
\hline $1-2$ & Every 4 weeks & 4 & 21 & 10 & 21 \\
\hline 3 & Every 4 weeks & 4 & 21 & 10 & \\
\hline 4 & Every 4 weeks & 6 & 31.5 & 10 & 21 \\
\hline 5 & Every 4 weeks & 6 & 31.5 & 10 & \\
\hline 6 & Every 4 weeks & 6 & 31.5 & 10 & 21 \\
\hline 7 & Every 4 weeks & 6 & 31.5 & 10 & \\
\hline 8 & Every 6 weeks & 10 & 52.5 & 10 & 21 \\
\hline 9 & Every 6 weeks & 10 & 52.5 & 10 & \\
\hline 10 & Every 6 weeks & 10 & 52.5 & 10 & 21 \\
\hline 11 & Every 6 weeks & 10 & 52.5 & 20 & \\
\hline $12+$ & Every 6 weeks & 16 & 52.5 & 20 & 21 \\
\hline $\begin{array}{l}\text { a Menzel et a } \\
\text { b Adapted frc } \\
{ }^{\mathrm{c}} \text { NPK formul } \\
{ }^{\mathrm{d}} \text { Products su } \\
\text { e Products su }\end{array}$ & $\begin{array}{l}\text { 93) and Newett et al. (199 } \\
\text { ewett et al. (1999) and Ba } \\
-9,6-6-6 \text {, or similar } \\
\text { KeyPlex }{ }^{\circledR} \text { mixed in } 30 \text { ga }\end{array}$ & gartner (1987) & it den & norying & \\
\hline
\end{tabular}

